\title{
DỨBin
}

Technological University Dublin

ARROW@TU Dublin

\section{Social class tensions, habitus and the advertising of Guinness}

John Connolly

Dublin City University, John.Connolly@dcu.ie

Paddy Dolan

Technological University Dublin, paddy.dolan@tudublin.ie

Follow this and additional works at: https://arrow.tudublin.ie/aaschsslarts

Part of the Sociology Commons

\section{Recommended Citation}

Connolly, J., \& Dolan, P. (2017). Social class tensions, habitus and the advertising of Guinness. The Sociological Review, 65(1), 100-116. https://doi.org/10.1111/1467-954X.12388

This Article is brought to you for free and open access by the Social Sciences at ARROW@TU Dublin. It has been accepted for inclusion in Articles by an authorized administrator of ARROW@TU Dublin. For more information, please contact arrow.admin@tudublin.ie, aisling.coyne@tudublin.ie,gerard.connolly@tudublin.ie.

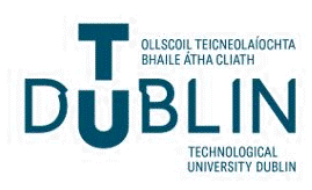




\title{
Social class tensions, habitus and the advertising of Guinness
}

The Sociological Review 2017, Vol. 65(I) 100-116 (C) The Author(s) 2016

Reprints and permissions: sagepub.co.uk/journalsPermissions.nav DOI: 10.111 I//467-954X.12388 journals.sagepub.com/home/sor

(9SAGE

\author{
John Connolly
}

Dublin City University, Ireland

\section{Paddy Dolan}

Dublin Institute of Technology, Ireland

\begin{abstract}
Drawing from an Eliasian perspective we examine how an 'advertising subjectivity' became more firmly embedded within the bourgeois habitus. We explain how and why advertising slowly developed and expanded within a commercial organization despite initial opposition, ambivalence and even hostility from some of its bourgeois senior management towards the practice - the very social class sometimes identified with advertising's origins and advance. Our empirical case is based on Arthur Guinness \& Sons Ltd, the Irish company which came to be renowned for the alcohol beverage which carried its name - Guinness stout. We explain how the development of advertising was impelled by a series of processes that increasingly interlocked; a widening and intensification of competitive commercial interdependencies; a shift in the power balance between the bourgeoisie and aristocracy in favour of the former in Britain; and by a changing consumer habitus in several different nation-states. Central though, as we illustrate, was a process involving the changing power relation between various social classes in Britain - principally the increasing power chances of bourgeoisie in relation to the aristocracy - a process that had advanced considerably by the turn of the twentieth century.
\end{abstract}

\section{Keywords}

advertising, Elias, figurations, Guinness, habitus, social class

\section{Introduction}

Consumer subjectivity, its development and the wider culture it comprises, have been described, explained and theorized by both sociologists and historians alike in a variety of spatial-temporal contexts (Cohen, 2003; Dolan, 2009; Ewen, 1976; Miller and Rose,

\section{Corresponding author:}

John Connolly, Dublin City University, Glasnevin, Dublin 9, Ireland.

Email: john.connolly@dcu.ie 
1997; Trentmann, 2006). Thus, the notion of the consumer having an ahistorical and unchanging essence has been long dispelled. However, the same cannot be said in relation to those who engaged in advertising on the producer side to anywhere near the same extent. Despite a growing body of work directed at the production of advertising, particularly in relation to the subjectivity of contemporary advertising functionaries and of the social context in which they operate (see Cronin, 2004; Hackley, 2003; Moeran, 1996; Moor, 2008; Nixon, 2003), there remains, as McFall notes, little in relation to 'the empirical history of advertising production' (2004: 5). Historians have to some extent sought to bridge this gap through narratives of the development of advertising in various countries (Nevett, 1982; Oram, 1986; Church, 2000). Yet, as with more sociologically informed work it is presumed that advertising was a function of a rising bourgeoisie and the motivations and compulsions that increasing industrialization and commercialization propelled (see Lury, 2004: 19; Williams, 2000 [1980]).

Drawing from the figurational sociology associated with Norbert Elias (2000) we explain how a policy of overt advertising gradually developed within a commercial organization even though such advertising practices were initially considered distasteful by some bourgeois managers - from the very class position often associated with advertising's advance. We stress that assumptions of hostility, ambivalence or enthusiasm for advertising cannot simply be superimposed on imagined static class positions, but instead must be understood in terms of the changing power relations between classes, themselves understood as relational identifications in process. Our empirical case is Arthur Guinness \& Sons Ltd, ${ }^{1}$ the Irish company famous for the production of Guinness stout. In 1853 the Pharmaceutical Journal noted "“[Guinness] will not condescend to puff [promote] their stout"' (cited in Strachan and Nally, 2012: 3). Significantly, this policy largely endured through to the late 1920s when it changed with the initiation of direct advertising campaigns and the formation of an advertising department.

Though the subjectivities of consumers and advertisers have been recurrent themes of Foucauldian work on consumer culture, we propose a more figurational conceptualization of a person's self-steering capacities and dispositions. In this framework such dispositions are connected to cultural codes and standards which emanate from dynamic networks of mutual dependencies between people (figurations) over generations. Codes and standards change in various positions within the figuration and particular individuals experience contradictions between already formed dispositions and new social conditions, thus producing mixtures of realignments, resentments and accommodations. In this model neither the advertiser nor the consumer possesses power, as these social functions exist within a broader web of social interdependencies. Foucauldian approaches also ostensibly eschew the notion of power as possession, yet still see relatively direct relations between expert discourses, discursive practices and effects. For example, the consumer is seen as assembled differently depending on the particular version of psychological theory implemented in advertising practice (Miller and Rose, 1997). Miller and Rose examine how the psychological discourse of rationality was brought to bear on Guinness drinkers in research studies at the Tavistock Institute of Human Relations. However, just because a particular psychological model of the person was used to understand drinkers does not mean that those drinkers always acted rationally in their consumption of Guinness. (Miller and Rose also note that another version of the rational 
Guinness drinker took personality into account, but again this is simply an outcome of the use of personality theories, and so discourses are seen to assemble subjectivities.) Here, we are not proposing the primacy of expert discourses on the dispositions of Guinness managers and proprietors, but rather that the changing power relations and associated forms of status competition between social classes facilitated different emotional valuations of advertising practice.

A range of sociological, cultural and historical studies of advertising have tended to conceive of advertising as emanating, either implicitly or explicitly, from the intentions of powerful capitalist actors (see, for example, Cohen, 2003; Cross, 2000; Ewen, 1976) - here, too, individuals and corporations are often conflated - symbolized for instance by Stuart Ewen's (1976) abiding metaphor, for 'The Captains of Industry'. Leaving aside the old determinist critique, it further presupposes that capitalist business owners and management had a favourable disposition towards advertising. We contend that those who instigated advertising and marketing in an effort to persuade 'consumers' to purchase their offerings had also developed a habitus in which such practices came to be conceived as necessary, acceptable and 'normal'. Indeed, considerable historical evidence exists to support this; Cronin (2004) notes that there was a marked reluctance on the part of many commercial business owners in the 1800 s and early 1900 s to advertise. For Cronin, much of this unwillingness to advertise was on the grounds of perceived uncertainly around 'the persuasive potential' of advertising (2004: 24). Others noted the pernicious image of advertising throughout the 1800s following the often unscrupulous advertising activities and promises of some medical practitioners in both Ireland and Britain (Nevett, 1982; Reinarz, 2007; Strachan and Nally, 2012). This perhaps contributed to the reluctance of some to engage in the practice ${ }^{2}$ or alternatively to adopt a more discreet approach (Church, 2000). Yet, as an overall explanation for the ambivalence or hostility towards advertising it is somewhat problematic in that there remains considerable evidence (see Gutzke, 1984; Reinarz, 2007) to suggest, as we do here, that a wider class prejudice overshadowed this.

In Church's (2000) detailed review of historical studies he suggests the rise of advertising in nineteenth-century Britain was linked to several developments, including - the falling price of industrially produced goods; increased 'producer' competition (facilitated by improvements in the transport network); changing social standards concerning hygiene and health; a reduction in advertising costs and the emergence and expansion of the function of advertising agent; and what he described as 'technical changes' which allowed greater scope for more varied and novel forms of advertising. Our explanation neither rejects nor contradicts this - in fact there are several parallels with our analysis. Rather our contention is that such developments were interwoven with changes in the structure of social class relations that served to shape, and change, the emotional meaning of advertising.

Class, too, is considered by Church in two respects. On the one hand, he discusses it in relation to the social cohorts at which nineteenth-century advertising was directed, and on the other, and more significantly in the context of this paper, he also alludes to debates concerning the 'embourgeoisement' ${ }^{3}$ (original emphasis) of the working classes - the absorption of middle-class values and behaviours by members of the working classes in explaining expanding consumer markers and related advertising efforts. Again, while 
we don't disagree that this was a feature in explaining the overall expansion of advertising, it marginalizes the tensions and conflict between upper- and middle-class groups in Britain, particularly in the 1890s. As such, Church implicitly conceives of British class relations as bipartite - tensions, hostilities and accommodations between the aristocracy and middle-classes are ignored or downplayed. In that regard, there are parallels between Church and Perry Andersons's (1964) earlier analysis of British class relations. Anderson's primary contention is that the English aristocracy and bourgeoisie came to form a single class quite early in England - mainly based on aristocratic values and attitudes, perhaps best exemplified by his suggestion: 'There was from the start no fundamental, antagonistic contradiction between the old aristocracy and the new bourgeoisie' (1964: 3, original emphasis). Such a conclusion differs from both Elias (2008 [1986]) and Dunning and Sheard's (1979) analysis from which this paper draws in explaining the shifts in policy at Guinness. Despite some parallels with Anderson's overall analysis, they offer a more processual account of British class relations. Here tensions, divisions, hostilities, and integrating and assimilating patterns - both inter- and intra-class - interweave and change in conjunction with changing power ratios involving the aristocracy (and gentry), the bourgeoisie and the working classes. For Elias (2008) the aristocracy and gentry were distinct social groups - a crucial element in the parliamentary structure that emerged in England and the process of pacification connected with it - yet as landowning classes they were united not just by their mutual interest as landowners but also:

by a cultural tradition of their own which distinguished the landed classes, nobility and gentry alike, from other social classes whose male members were not considered, in terms of their social rank as well as their manners, to be 'gentlemen' (2008: 15).

Anderson and Elias agree that there were common interests and cultures between the aristocracy and gentry, which facilitated a less violent, though gradual, 'parliamentarisation' (Elias, 2008). Yet for Elias, a rising bourgeoisie did occur through processes of industrialization, and the entrepreneurial middle classes were not simply co-opted into aristocratic codes. Here, Elias (2000: 430-431) makes a distinction between individual and collective social mobility. Where occasional individuals ascend to higher classes, often the former class habitus has to be remoulded or hidden to enable smoother integration and social survival. But collective social mobility tends towards the assertion and even amplification of distinct class cultures and codes of conduct, the confident expression of bourgeois rationality against the luxurious profligacy of the aristocracy, for example. Anderson (1964: 32) argues that middle-class cultural goals from the mid-nineteenth century were largely restricted to individual ascent through integration. However, Thompson (1965: 326-327) identifies many social institutions of the nineteenth century, such as the police and municipal government, as thoroughly middle class, indicating the growing assertion of such middling groups. Citing Beatrice Webb, Anderson also argues that the aristocracy exercised decreasing control over admission to London Society (1964: 329), which included brewers. It is likely that the status anxiety experienced by early ascenders of the brewing industry led to greater deference to aristocratic codes, but later collective mobility of the middle classes diminished the shame of acquiring wealth through commerce alone, even within these upper-class social circles. It has also been 
noted that Anderson pays insufficient attention between different class fractions within capitalism - the antagonisms between the northern, industrial capitalists and the southern, finance capitalists (Hickox, 1995; Nicholls, 1988; Rubinstein, 1977).

In this paper we explain how the transformation that occurred in relation to advertising was connected to changes in the structure of interdependencies at different, yet interconnected, levels of social integration. Central though, as we illustrate, was a process involving the changing power relation between various social classes in Britain - specifically, the increasing power chances of bourgeoisie vis-à-vis the aristocracy ${ }^{4}$ - a process that had advanced considerably by the turn of the nineteenth century (Dunning and Sheard, 1979).

As indicating, this study was informed by the theoretical approach of Norbert Elias (2000). A central aspect of Elias's theory is the relationship between changes in the social habitus of individuals and changes in the social structure of society. One of the main concepts deployed in explaining this is that of figuration - fluid networks of interdependent people characterized by shifting power ratios. He used the concept to counter what he saw as the antithetical assumptions implicit in the deployment of concepts such as 'individual' and 'society' or 'agency' and 'structure' and their seemingly fixed, static nature (Elias, 1978 [1970]). Instead, Elias claimed people comprise multiple and changing figurations at different levels of integration and size - from the level of family up to the level we identify as global society. Moreover, Elias demonstrated theoretically and empirically how figurational dynamics - changing power relations and dependencies between social groups - become channelled into, and subsequently manifest, in various social practices; table manners, general etiquette, leisure and sporting practices being examples. Though unplanned, this process has a direction, albeit subject to reversals and discontinuities, which he referred to as 'civilising', involving a growing social constraint towards self-restraint over an ever-increasing range of behaviours and feelings and in ever more social situations. As part of this process, not only are particular social practices stigmatized, considered more shameful or come to be considered taboo, the individual conscience also becomes a greater regulator over them.

Elias (1996) also explained how state formation processes and the related past social conflicts and tensions connected with these can become deeply sedimented within the habitus of groups shaping later social interactions and thinking. The feelings generated through these past interdependencies become internalized to such an extent they find expression as national or class characteristics over generations. In this way Elias explained how the social habitus is shaped by both past and ongoing interdependencies. While it is not possible in any significant way to relay Elias's theory here, the aim of this brief summary is to illustrate how his long-term developmental, comparative, approach involving the dynamic of social and self-regulation reflected through the social habitus, and the related concepts of figuration, process and power were central to the ongoing analysis and interpretation of data while simultaneously guiding further data searching and selection.

\section{Data sources and approach}

The genesis of this study emerged from an examination by the authors of archival material at Arthur Guinness \& Sons Ltd at St James Gate Brewery in Dublin, Ireland and in the 
related analysis of historical monographs relating to the company. While the reluctance by the Guinness company to advertise prior to the 1920s had previously been noted it tended to be rationalized by the suggestion it emanated from some of the senior management's belief in the superiority of Guinness products (see Dennison and MacDonagh, 1998: 173; Hughes, 2006: 159). That such a view was expounded by some at the apex of the company perhaps partly sustained such an explanation - and by the relative commercial success of Guinness, particularly in respect of Ireland. Sociologically, such explanations appear unconvincing. Implicitly, they assume not only the outright omnipotence of key individuals but the persistence of this across time. Equally, such accounts leaned heavily towards economic determinism by locating the shift in policy within the declining market fortunes of Guinness in Britain at the time. While there are economic aspects to our explanation it was neither decisive over, nor detached from, other social processes.

Our empirical data was derived from a wide selection of documentary materials covering the period 1880-1960. ${ }^{5}$ The extensive archive at the Dublin brewery provided papers that gave an insight into the management and development of the company in Ireland, Britain, Europe, North Africa, Australasia and North, South and Central America. This was supplemented by an analysis of histories of Arthur Guinness \& Sons Ltd, of which there were several; biographies of the Guinness family; socio-historical accounts of the wider brewing industry, the advertising industry, and of nineteenth- and twentiethcentury consumer culture more generally; prescriptive manuals for the conduct of advertising that emerged at the turn of the twentieth century; an analysis and selection of local and national newspapers in both Britain and Ireland; and broader socio-historical monographs of Ireland and Britain.

\section{Class tensions and 'dignity' in advertising}

Central in explaining the change in policy towards advertising at Arthur Guinness \& Sons Ltd during the early twentieth century was a process involving the changing power relation between various social classes in Britain. Industrialization, and trade and commerce connected with this, had facilitated an advance in the power chances of the bourgeoisie relative to the established aristocracy and gentry, particularly by the 1850 s (Dunning and Sheard, 1979). While the aristocracy still retained their position as the ruling elite, growing insecurity emanating from the threat from below impelled the desire for social distance from the bourgeoisie. Interrelated with this they sought to stigmatize and redefine the meaning of various social practices associated with the 'men in trade' (Gutzke, 1984) - the bourgeoisie. In this social context a declining aristocracy targeted the very source of bourgeoisie power - commerce. Commercial activities such as advertising and promotional exhibitions were imbued with the stain of inferiority, something to be avoided or hidden from one's social milieu (see Rains, 2010). Such practices functioned as a system for distancing the aristocracy from the bourgeoisie.

Over the course of the latter half of the nineteenth century, the balance of power gradually swung more in favour of the bourgeoisie (Dunning and Sheard, 1979). The fact that the aristocracy, though declining, were still the elite stratum in British society meant that such advancement was far from guaranteed and tended to generate considerable status anxieties amongst many members of the bourgeoisie. Even by late 1800s many 
brewers and businessmen still encountered aristocratic attempts to thwart their social ambitions (Gutzke, 1984). To that extent, the aristocracy remained a reference group for many socially ambitious members of the bourgeoisie.

While the power chances of the bourgeoisie had advanced, they still remained dependent on the aristocracy due to the aristocracy's capacity to facilitate or restrict their chances of further status enhancement. Consequently, the partial aristocratization of the bourgeoisie was also a feature of this process ${ }^{6}$ (Dunning and Sheard, 1979). Brewers, like other businessmen, took on some of the practices, etiquette and values of the aristocracy while simultaneously suppressing the source of their social advancement (Gourvish and Wilson, 1994; Martelli, 1956). It is this social context that helps explain how advertising was understood by those at the apex of Guinness and the attitudes they held.

The social origins and trajectory of the Guinness family since the founding of the brewing business in the eighteenth century are complex and do fit within a simple bourgeois-aristocracy binary. Arthur Guinness, the founder of the porter brewing business in 1759 , was of bourgeois origins - the son of a land steward he also became a successful member of the merchant class (Guinness, 1998). The proceeding centuries would see the gradual integration of members of the Guinness family into the aristocracy - Benjamin Lee Guinness (grandson of the founder) became a baronet in 1867 (Mullally, 1981). Despite this social advance, or perhaps because of it, the next generation of Guinness's Benjamin Lee's sons - experienced considerable status anxiety as they sought greater acceptance amongst older, and more established, members of the nobility. They experienced, though at varying levels, embarrassment and shame feelings ${ }^{7}$ over the very practices which had generated their power sources (Martelli, 1956; Mullally, 1981). Benjamin Lee's third son, Edward Cecil Guinness, became sole proprietor of the company in 1876 (he too would gradually ascend the ranks of the nobility ${ }^{8}$ ); he and his brother Arthur Edward inherited the business in 1868 (Dennison and MacDonagh, 1998). Although a significant figure in Irish society by the 1880 s, Edward Cecil owed this to the wealth obtained through commerce as opposed to inherited wealth from land. Edward Cecil and his wife, despite their position remained socially ambitious, keen not only to be further integrated in the upper circles of Irish society, symbolized through invitations to social engagements at the Vice Regal lodge ${ }^{9}$ in Dublin, but also, increasingly, London society (Martelli, 1956; see also, Irish Times, 7 July 1879) and the social standing this expressed. This was a manifestation of the mutual accommodation and value fusion that had emerged between the bourgeoisie and aristocracy referred to above. At the same time, it illustrates how despite their rising power chances, the Guinness family, and the bourgeoisie generally, were still to a significant extent dependent on members of the aristocracy for access and integration into the upper circles of society. The American writer and diplomat at the United States consulate in London in the 1870 s, Adam Badeau, ${ }^{10}$ writing on his experiences in 1885 noted: 'Wealth everywhere that is not inherited, whether acquired by manufactures or commerce or whatever means, seeks to bask in the favor of the nobility, is ambitious of their connection, craves admission to their company' (1885: 283).

It was in that social context, that advertising, despite its increasing application as a commercial practice over the course of the nineteenth century in Britain (Nevett, 1982), could still generate ambivalent feelings for many business owners. Not only was it an offshoot of commerce, more significantly, it functioned to amplify one's engagement in 
commerce. Even by the turn of the century, commerce for some was still felt to be 'tainted' and an activity that some successful practitioners still felt somewhat 'ashamed' of (see Daily Mail, 22 October 1902: 2). Consequently, advertising was, outwardly at least, distained by some members of a socially ambitious and rising bourgeoisie, such as Edward Cecil Guinness, who had managed to integrate themselves into the elite of society and had become ennobled. And evidence would suggest that Edward Cecil was not unique in this regard. As late as 1910, in The Irish Year Book 1910, published by individuals drawn from the Irish commercial classes, exponents of advertising penned an article entitled 'The Advertising Problem'. In targeting the reluctance of 'old established firms' to advertise, the author of the piece notes: 'It is sometimes argued by these firms that advertising is undignified, and that should they adopt it they would suffer a loss of prestige' (1910: 309). Here was evidence of lingering upper-class stigma. The word 'dignity' had aristocratic connotations, being a synonym for ennoblement (see Badeau, 1885). As such, the classification of practices as dignified or undignified was connected with maintaining social barriers. Thus, in a society where social demarcations mapped rising social tensions, concerns about the dignity of advertising remained a significant problem for those actively seeking to promote the practice in both Ireland and Britain (see Huddersfield Daily Chronicle, 24 July 1899: 4; Burnley News, 25 March 1916: 9; Northern Daily Mail, 30 April 1925: 8). For instance, in 1911 The Evening Telegraph and Star (31 March 1911: 5) reported a lecture by Thomas Russell, president of the incorporated society of advertising consultants, to a group of businessmen in Nottingham. In a part of the report under the subheading 'No loss of Dignity' it stated: 'In many centres - and he was told it was particularly so in Nottingham - large traders, manufacturers, and wholesale dealers objected to advertising because they thought that either it might disturb trade relations, or that it was undignified.'

As commercial demands on Guinness increased during the early 1900s Edward Cecil acceded to the pressure to advertise in some of Guinness's European markets. Despite this, his ambivalence towards advertising remained. Advertising was to be permitted on the 'continent' (mainland Europe) as it differed from 'that in Great Britain' for 'he [Edward Cecil] did not see any objection to advertising there, as would be the case in England'. Furthermore, he cautioned for 'the need for dignity in advertising' preferring 'the advertisements to appear to emanate from the bottlers rather than the company' (Hughes, 2006: 30). In this way, advertising was more distant, 'behind the scenes' (Elias, 2000), its shame associations hidden somewhat from the social circles in which Edward Cecil frequented. Of course, despite the social elevation his family had experienced Edward Cecil still held many of the values and interests that were bourgeoisie, and aspects of his habitus, despite his efforts, still betrayed this - the economic was still important. Equally, the presence of Guinness in markets across the globe acted as a form of social prestige amongst his 'commercial' peers so there were contradictory emotional pulls. Nevertheless, it is this desire to maintain distance, the class tension and felt insecurities underpinning it, that explain, in part, the policy of advertising by Guinness in both Ireland and Britain at that time.

It is important to emphasize that the decision to advertise in continental Europe should be conceived processually. What we mean here is that that decision should be construed as a further step in the move towards more overt advertising rather than the initiation of 
advertising per se; a position that has symmetries with Reinarz's (2007) analysis of nineteenth century beer advertising. Prior to this the promotion of Guinness was widespread though primarily directed and controlled by and through intermediaries.

Over the course of the first two decades of the twentieth century, the policy and attitude towards more direct and extensive advertising at Guinness would change despite the continuing presence of Edward Cecil as chairman. In the late 1800s and early 1900s senior management at Guinness comprised members of the extended Guinness family. It also included several recruited externally such as C. D. La Touche, T. B. Case, F. E. Greene and C. J. Newholm (Guinness archive). It is from this group, Newholm in particular, that a greater push for more direct advertising would emanate. As members of the bourgeoisie, many of them had been educated at public schools in Britain such as Winchester and Charterhouse (Dennison and MacDonagh, 1998; Hughes, 2006). This is significant in that they entered these educational establishments at a time when the power chances of the bourgeoisie were more advanced in comparison to the 1850s (Dunning and Sheard, 1979). As such, they were socialized into, and more confident in holding, a set of values and ethos which was 'purer bourgeoisie'. Furthermore, following their education, they entered into careers within industry and commerce at a time when it was becoming clearer the bourgeoisie were now a socially stronger tier of British society, and commensurate with this the taint of commerce diminished. These combined processes meant they were less insecure with engaging in commercial activities and openly expressing this. ${ }^{11}$

Indeed, it is this shift in the power balance between the classes which also explains the more accommodating attitude towards advertising held by Edward Cecil's son, Rupert Edward. Rupert Edward was more smoothly integrated into the elite of British society (one increasingly comprised of the bourgeoisie). Moreover, he now entered the company at a time when commercial activity was considered a more gentlemanly practice and, as such, he could be more secure in his favourable attitude to advertising at Guinness.

The changing social structure in Britain, which had favoured the bourgeoisie, accelerated further by the 1920s. The aristocracy and gentry had continued to decline in terms of overall position and power in society, increasingly superseded by the elite of the industrial classes. Indeed, the main axis of tension was now between bourgeoisie groups on the one hand and working class groups on the other (Elias, 1996: 164). Advances in industrialization and the changing balance of power it impelled meant the position of the working classes had strengthened since the 1870 s, culminating in a political voice in parliament and subsequently government by the mid-1920s (Royle, 1997). As the axis of class tension shifted, the taboo towards advertising dissipated further, though it did not disappear entirely. The expansion of the industrial classes also generated another development which also led to the further de-stigmatization of advertising. The increase in industrialists was accompanied by the creation and expansion of new and existing white collar functions, many of which emanated from the competitive interdependencies between commercial organizations. Increasing numbers of the lower middle classes and working classes were employed in sales and other related functions across the chain of manufacturing, distribution and retailing (Church, 2008). More significantly, they were drawn from a social cohort for whom commercial activity carried no social stigma. As such, commercial organizations became increasingly permeated at all levels by those 
who viewed advertising and other promotional activities as legitimate and both socially acceptable and rewarding.

One manifestation of the increasing power of the bourgeoisie was a change in attitude to advertising, and in the wider discourse surrounding it, generally in commercial circles. For example, a series of six lectures again by Thomas Russell (given at the London School of Economics) in 1919, and subsequently published as a book, is instructive of the changes that had occurred. Targeted at the business community, Russell's primary motivation is the advancement of advertising, and in the course of doing this he addresses what he identifies as the 'prejudices' that had been, and continued to be, directed at advertising. His main target in that sense was what he considered the 'evil precedent' set by unscrupulous individuals in which advertising had become 'synonymous with claptrap and misrepresentation' (1919: 3). Significantly, his further expansion of this issue and his efforts at dispelling the concerns expressed by them are positioned within the framework and related compass of bourgeoisie morality and values (Wouters, 2007) the need for truth and trust in commercial relations. Only briefly is a hint of class antipathy touched upon and this to illustrate its disappearance:

In times not so long past, it would have required some temerity, in these academic halls, to broach the subject of these lectures. The times are changed, and I need not draw down the blinds to talk openly about Advertising. Prejudice dies hard, but is dying. (Russell, 1919: 45)

Despite this, and the social accent it reflected, not all members of the bourgeoisie were impervious to status anxiety as a result of their commercial activities. Neither commerce nor advertising had entirely lost the capacity, even at this point, to generate anxieties amongst those whose habitus had been deeply penetrated by earlier models of conduct and value setting. For instance, Gourvish and Wilson (1994: 223-224) note how in 1929, 'When Sir James Agg-Gardner [brewer], socially well connected, educated at Harrow and Trinity College, Cambridge, and many times MP for Cheltenham, wrote his autobiography, only once did he mention his brewing connections in 246 pages of parliamentary name-dropping'.

In the case of Guinness, although several of the senior management of Guinness, now primarily drawn from the elite industrial class and a cohort more socially secure in their own bourgeois values than in previous times, could express and act upon these attitudes and beliefs more openly and more confidently, an insecurity and ambivalence towards advertising still remained. This, in part, can be attributed to Edward Cecil's position within the figuration of senior management at Guinness over that period; it ensured that his attitudes and opinion, whether directly sought after or not, were considered by those at the apex of the company (Dennison and MacDonagh, 1998: 31).

On the other hand, it also demonstrates how previous social tensions, and the pressures and compulsions it generated, had become deeply ingrained in the habitus of particular social groups. Even amongst a newer generation of Guinness management there remained a concern with the image and type of advertising. Indeed, this is evident from the discussions prior to the decision to advertise directly in 1927. One of the leading advocates for advertising in the company at that time was C. J. Newbold, a former England rugby international, who had been educated at the English public school 
Uppingham. In a report on the British market to the board in February 1927- which clearly identified that sales had fallen significantly during the 1920s - Newbold, amongst a number of recommendations, advocated the use of greater advertising. However, he tempered his calls with the suggestion that the "advertising should be "careful" and as far as possible "indirectly through our customers [bottlers]" (Dennison and MacDonagh, 1998: 173). By placing it through their 'customers' it masked the Guinness association - essentially it was pushed behind the scenes - an indication that a level of shame feeling remained towards its more overt deployment.

Prior to the board meetings in Dublin on 30 August and 2 September 1927, at which an advertising budget of between $£ 10,000$ and $£ 15,000$ was approved for the campaign in Scotland (Dennison and MacDonagh, 1998: 174) and for a reserve fund of $£ 10,000$ 'for overseas publicity', Edward Cecil's sanction had already been obtained. Despite this, Newbold suggested: 'slate tablets outside public houses, similar to those of Bass and Worthington [competitor brewers]' - they were 'excellent advertisement ... quiet and dignified in appearance' (Dennison and MacDonagh, 1998: 175). The expressions of 'quiet' and 'dignified' had the connotation of an older gentlemanly behaviour, honourable, regal and respectable. Above all, it suggested the values the modern gentleman could associate himself with and, though it went unmentioned, what he should avoid, the 'loud' and 'vulgar'. That advertising was now being considered in this way most certainly reflected the advance of the bourgeoisie and of their social security and aspirations. However, the emphasis and felt necessity to differentiate the forms of advertising still reflected lingering social anxieties around such practices and the fear of social failing that could ensue. The function of this discourse was to affirm that one could remain a gentleman while still engaging in such overt promotional activities. Of course, the figuration formed by those involved in this discussion partly shaped the nature of the dialogue. Edward Cecil Guinness's presence ensured that Newbold, and others, were cautious and careful in describing their push for greater and more overt advertising. Yet, as will be illustrated later, they too retained a social disposition shaped by the interpenetration of bourgeois and aristocratic values in which advertising retained the taint of 'vulgarity'.

\section{Social class, competitive pressures and the advocates for advertising}

As the degree of competitiveness pervading the British brewing industry increased at the turn of the twentieth century the functional importance attributed to promotional activities increased across the wider brewing figuration (Reinarz, 2007). One manifestation of this was the increasing number of direct appeals to brewers from intermediaries - those in retailing and distribution functions - to support their promotional efforts in both domestic and export markets. Mutual interests and bonds fostered through the pursuit of these markets also facilitated a level of understanding amongst senior Guinness management of the competitive pressures exerted on intermediaries. For instance, in 1898, C. D. La Touche, then assistant managing director at Guinness, consented to financial supports for the advertising of Guinness by intermediaries in the USA (Dennison and MacDonagh, 1998: 68). This was not necessarily a sudden rupture with past thinking but rather an 
advance in the process whereby advertising was becoming more acceptable and employed at Guinness. In 1896 bottlers of Guinness were required to 'include, and give due prominence to, Guinness's name as the manufacturers on their own bottlers' labels' (Dennison and MacDonagh, 1998: 63) - a recognition of the importance of the brand name in the retail environment. Yet, the attitude towards advertising remained ambivalent. In a response by La Touche to the managing director of one of Guinness's intermediaries Reads Bottlers - for either direct or indirect support for advertising in 1909, he stated "we never advertise in this or any other way" (cited in Dennison and MacDonagh, 1998: 72). Conversely, and despite the earlier rebuke, by 1911 advertising allowances were being given to Guinness agents in Belgium for advertisements (Guinness, 1911).

Nevertheless, bottlers, distributors and retailers continued to appeal for both advertising supports and direct advertising by Guinness (Guinness, 1926). As part of these entreaties the application and extent of advertising by other brewers were persistently invoked as was the seductive power of advertising. For example, in April, 1927, the secretary of M. B. Foster, an overseas distributor of Guinness wrote to the company enquiring if they would assist their advertising - 'the most efficacious method of popularising our bottling of your Foreign Extra Stout is by means of a very liberal distribution of advertising material' (Guinness, 1927). As before, there was general acceptance within senior management at Guinness that bottlers needed to be supported in terms of advertising allowances and in 1927 the board of Guinness in Dublin agreed to give monetary grants to bottlers for overseas advertising (Guinness, 1927). The pressure from bottlers to advertise constituted a wider commercial environment in which advertising was increasingly advocated and practised. The interconnected processes of migration to urban centres, the expansion of commercial and industrial functions, and the intense competition generated by expanding functional specialization facilitated and impelled the emergence and growth of advertising practices. The growth of the urban population generated new social pressures and new social functions. Urban living and working meant people become more reliant on others for the provision of various social needs and new commercial enterprises emerged to fulfil this gap. Increasing numbers of the lower middle classes in the search for employment, and other commercial and social opportunities, embraced and developed existing and new social functions within an expanding commercial sphere. Impelled by expanding competitive interdependencies advertising came to be perceived as an essential practice through which many of the new commercial classes could sustain or enhance their economic and social position - including the providers of advertising and the functions connected with this. Indicative of this was the increasing number of advertising agencies emerging (Nevett, 1982: 100; Strachan and Nally, 2012: 23).

Exponents of advertising were keen to laud its benefits, and necessity; hardly surprising given that many businessmen remained unconvinced as to the commercial benefits of advertising. Considerable psycho-social power was attributed to advertising as a means to motivate people to purchase particular goods while advertising agencies sought to position these activities as specialist skills. It was not only advertising functionaries and specialists that sought to elevate the status and functional import of advertising. Newspaper proprietors and others within the distribution and production chain of advertising sought to propel both the overall status of advertising and the effectiveness of their specific role in advertising's persuasive properties. Thus, functionaries in positions across a whole 
series of interwoven figurations pushed the use of advertising owing to the self-escalating competitive pressures produced by this constellation of interdependencies.

The pressure for advertising also emanated directly from Guinness employees, namely what were known as the 'Guinness travellers' (Dennison and MacDonagh, 1998), particularly from the early 1900s. Indicative of this was a letter from one such traveller stating:

we do urgently require some additional advertisement of an attractive nature for our manufacture, in the light of the very energetic and effective campaign pursued by Mitchells and Butlers, and other local Breweries in furtherance of the sale of their products. (Guinness, 1926)

Many of the commercial travellers employed by Guinness tended to be strong adherents for advertising. Not only was their employment and identity closely connected with commercial activity, given the frequency in which they espoused the greater use of advertising by Guinness they lacked many of the insecurities felt by some of those positioned in higher level functions at Guinness. Thus, like many of Guinness's middle-class employees, and most certainly those of senior management drawn from the elite of the bourgeoisie, they comprised figurations in which both their career and wider social position required considerable self-monitoring and regulation. However, we argue that while the maintenance of social, and professional, respectability was shaped to a large degree by the social values of bourgeois society it was also one which was infused with aristocratic orientations (Elias, 1996). This in turn partly shaped their attitudes to advertising. One reflection of this was the tendency, in parallel with appeals for advertising, to temper such calls by differentiating between categories of advertising and between the mediums associated with them. For example, one Guinness traveller in England, Mr Mercer, in his report in 1926 stated:

Owing to the great change which has taken place during recent years in the attitude of business firms generally towards the value of advertising, it may now be conceded that no firm of however high a standing can afford to do without advertisement in some shape. There are two forms of advertising - the 'Blatant' and the 'Subtle' - to which I would draw your attention. The Blatant is, of course, the obvious method, e.g., front page of the Daily Mail ... but in my opinion, we do not at present stand in need of this class of advertisement. (Guinness, 1926).

While both tone and content convey an amenable attitude towards advertising, a clear effort is made to differentiate between styles of advertising. This demarcation illustrates the social insecurity it could still generate even amongst those at lower tiers of the company. Nor was this sensitivity expressed by Mercer a derivative of a social pressure emanating from Edward Cecil's still influential position in the company. For instance, two years after Edward Cecil's death in 1927, Paul, the Guinness representative in Belgium, in a letter to Newbold in April 1929 concerning the activities of Guinness retailers there stated:

By creating a trade on real sound lines in Antwerp he [the Guinness agent in Belgium] would expect that the demand would arise by inhabitants of and visitors to Antwerp from other parts of Belgium. We should then be in the position of getting the cafe proprietors to come to us for stout instead of our going to them to ask them to take it. This does not mean that we should 
cease to push trade, but it means that our position would be stronger and more dignified. (Guinness, 1929)

Here efforts to 'push trade' - overt selling and promotion - are conflated with being undignified. In that regard, despite the felt pressures for the need for 'advertising', and 'a much stronger selling organisation', as Newbold had previously suggested (Dennison and MacDonagh, 1998: 173) perceived overt promotional activity still carried the taint of vulgarity. However, by the end of the 1930s advertising was essentially stripped of much of the class stigma which had once shrouded it; instead, replaced by its increasing valorization.

\section{Conclusion}

In this paper we sought to explain how an 'advertising subjectivity' became more firmly embedded in the social habitus of members of the commercial classes, how it came to be considered in a more favourable light and viewed as a key function in commercial relations.

It is important to stress that our explanation cannot be generalized to all socio-geographic settings. There remains a need to examine different socio-cultural and spatial contexts, and for that matter within the context of different organizational or industrial settings. Even in both the space (Ireland and Britain) and historical period in our analysis not all brewers or bourgeois industrialists held the same feeling towards advertising though Edward Cecil was not unique. While advertising was valorized and driven by various functionaries both this and its wider acceptance was impelled by changing power relations. Advertising, its emergence and practice, needs to be understood in the context of shifting social relations at different planes of social integration. Historians have tended to identify Edward Cecil Guinness as the primary obstacle to the instigation of directly controlled and overt advertising, a position not entirely divergent from our analysis. Where we deviate is our contention for the need to locate Edward Cecil's position, and for the need to understand his motivations, within a series of dynamic figurations. Only then does a fuller explanation emerge. The 'greater permeability of stratum barriers in Britain' (Elias, 1996: 165) that facilitated a fusion of codes between the aristocracy and the bourgeoisie, and later sections of the lower middle and working classes, are central in addressing the question as to why Guinness advertising took the pattern of development it did.

Equally, while our explanation for the shift in policy towards advertising at Guinness was connected with the ascent of the economic bourgeoisie, and the interpenetration of both aristocratic and bourgeois social groups and their respective value sets, these were interwoven with a whole series of other changes at different yet interconnected levels of social integration. This included: changes in the structure and competitive tensions of the figuration of brewing, distribution and retailing; the expansion of advertising as a specialist function more broadly and competitive tensions between those comprising the figuration of advertising and marketing and the innovations and emulations this impelled; and a wider civilizing process which involved changing leisure and consumer practices, advances in individualization and greater (social and self) regulation of alcohol consumption. 


\section{Acknowledgements}

The authors wish to sincerely thank the archivists at the Guinness Archive, St James Gate, Dublin for their time and help.

\section{Funding}

The author(s) received no financial support for the research, authorship and/or publication of this article.

\section{Notes}

1. The Guinness brewing company was first established in Dublin, Ireland in 1759 by Arthur Guinness. Guinness is now owned by Diageo, Ireland.

2. Although social class tension is occasionally suggested implicitly in documenting various oppositional movements, social critiques and efforts to control advertising, it is assigned little or no significant part in explaining the resistance to advertising.

3. Dunning and Sheard (1979) conceive of embourgeoisement in a wider sense, involving not just the spread of middle-class values to the working classes but 'upwards' also amongst the aristocracy.

4. These were not homogenous and internally unified social groups and their very make-up would change somewhat as we explain in this paper. However, they are important collective social frames for distinguishing those at the apex of British society from groups below whose initial ambitions were entry to the elite strata in British society and later the unseating and replacement of those occupying that role.

5. By the time of Guinness's incorporation as a limited company in 1886, Ireland was part of the United Kingdom of Great Britain and Ireland (following the Act of Union in 1801). As a result, Ireland was governed by direct rule from the British houses of parliament in London. In 1921, following the War of Independence, Ireland was partitioned and the Irish Free-state (which later became the Republic of Ireland) comprising 26 counties attained independence from Britain. The other six Irish counties remained under (contested) British control.

6. The other side of this process was the 'partial bourgeoisification' of the aristocracy (see Dunning and Sheard, 1979) and was reflected by the increasing role of members of the aristocracy in commercial activity such as directorships.

7. Arthur Edward Guinness, Benjamin's first son, who inherited his father's baronetcy withdrew completely from the business; both Martelli (1956) and Mullally (1981) attribute this decision to his, and his wife's, social aspirations and the felt necessity to distance themselves from 'the trade'.

8. Edward Cecil received a baronetcy in 1885 and was later made a Baron in 1891 and an Earl in 1919.

9. The Vice Regal Lodge was the residence of the Lord Lieutenant of Ireland, the British monarchy's official representative in Ireland.

10. See New York Times, 21 March 1895.

11. Management at Guinness were shaped more by the shifting structure of British class relations rather than British-Irish relations, though these too had a class aspect.

\section{References}

Anderson, P. (1964). Origins of the present crisis. New Left Review, I(23), 26-53. Badeau, A. (1885). Aristocracy in England. New York, NY: Harper \& Brothers.

Church, R. (2000). Advertising consumer goods in nineteenth-century Britain: Reinterpretations. Economic History Review, LIII(4), 621-645. 
Church, R. (2008). Salesmen and the transformation of selling in Britain and the US in the nineteenth and early twentieth centuries. Economic History Review, 61(1), 695-725.

Cohen, L. (2003). A consumers' republic. The politics of mass consumption in postwar America. New York, NY: Alfred A. Knopf.

Cronin, A. (2004). Advertising myths. London: Routledge.

Cross, G. (2000). An all-consuming century. New York, NY: Columbia University Press.

Dennison, S. R., \& MacDonagh, O. (1998). Guinness 1886-1939. Cork: Cork University Press.

Dolan, P. (2009). Developing consumer subjectivity in Ireland: 1900-1980. Journal of Consumer Culture 9(1), 117-141.

Dunning, E., \& Sheard, K. (1979). Barbarians, gentlemen and players: A sociological study of the development of rugby football. Canberra: Australian National University Press.

Elias, N. (1978 [1970]). What is sociology? New York, NY: Columbia University Press.

Elias, N. (1996). The Germans. Cambridge: Polity.

Elias, N. (2000). The civilizing process: Sociogenetic and psychogenetic investigations. Cambridge, MA: Blackwell.

Elias, N. (2008 [1986]). Introduction. In N. Elias and E. Dunning, Quest for excitement. Sport and leisure in the civilising process (Revised Edition) (pp. 3-43). Dublin: University College Dublin Press.

Ewen, S. (1976). Captains of consciousness: Advertising and the social roots of consumer culture. New York, NY: McGraw-Hill.

Gourvish, T. R., \& Wilson, R. G. (1994). The British brewing industry 1930-1980. Cambridge: Cambridge University Press.

Guinness (1911). Company secretary trade papers. Unpublished manuscript, Dublin [GDB. CO05.02.0400015.01].

Guinness (1926). Company secretary trade papers. Unpublished manuscript, Dublin [GDB/ CO05.02/03.0003.02(2)].

Guinness (1927). Company Secretary trade papers. Unpublished manuscript, Dublin [GDBC005.02.050003.15].

Guinness (1929). English trade papers, Unpublished manuscript, Dublin.

Guinness. (1998). Papers of the directors of the Guinness Company, 1800-1998. Unpublished manuscript, Dublin.

Gutzke, D. W. (1984). The social status of landed brewers in Britain since 1840. Histoire sociale - Social History, XVII(33), 93-113.

Hackley, C. (2003). Account planning: Current agency perspectives on an advertising enigma. Journal of Advertising Research, 43(2), 235-245.

Hickox, M. S. (1995). The English middle-class debate. British Journal of Sociology, 46(2), 311 324.

Hughes, D. (2006). 'A bottle of Guinness please': The colourful history of Guinness. Wokingham: Phimboy.

Lury, C. (2004). Brands: The logos of the global economy. London: Routledge.

Martelli, G. (1956). Man of his time: A life of the first Earl of Iveagh. London: Tanner and Butler. McFall, E. (2004). Advertising: A cultural economy. London: SAGE.

Miller, P., \& Rose, N. (1997), Mobilizing the consumer. Theory, Culture \& Society, 14(1), 1-36.

Moeran, B., (1996), A Japanese advertising agency: An anthropology of media and markets, Oxford: Routledge.

Moor, L. (2008). Branding consultants as cultural intermediaries. The Sociological Review, 56(3), 408-428.

Mullally, F. (1981). The silver salver: The story of the Guinness family. London: Granada.

Nevett, T. R. (1982). Advertising in Britain: A History. London: Heinemann. 
Nicholls, D. (1988). Fractions of capital: The aristocracy, the City and industry in the development of modern British capitalism. Social History, 13(1), 71-83.

Nixon, S. (2003). Advertising cultures. London: SAGE.

Oram, H. (1986). The advertising book. Dublin: MO Books.

Rains, S. (2010). Commodity culture and social class in Dublin 1850-1916. Dublin: Irish Academic Press.

Reinarz, J. (2007). Promoting the pint: Ale and advertising in late Victorian and Edwardian England. Social History of Alcohol and Drugs, 22(1), 26-44.

Royle, E. (1997) Modern Britain: A social history 1750-1997 (2nd edn). London: Arnold.

Rubinstein, W. D. (1977). Wealth, elites and the class structure of modern Britain. Past and Present, 76(1), 99-126.

Russell, T. (1919). Commercial advertising: Six lectures at the London School of Economics and Political Science (University of London). London: G.P. Putnam's Sons.

Samuel Deacon Ltd (1887). Deacon's newspaper handbook and advertiser's guide (8th edn). London: Samuel Deacon \& Company.

Strachan, J., \& Nally, C. (2012). Advertising, literature and print culture in Ireland, 1891-1922. Basingstoke: Palgrave Macmillan.

Thompson, E. P. (1965). The peculiarities of the English. Socialist Register, 2(2), 311-362.

Trentmann, F. (Ed.) (2006). The making of the consumer: Knowledge, power and identity in the modern world. Oxford: Berg.

Williams, R. (2000 [1980]). Advertising: The magic system. In Problems in materialism and culture, (pp. 170-195). London: Verso; reprinted in Advertising \& Society Review, 1(1).

Wouters, C. (2007). Informalization. manners and emotions since 1890. London: SAGE. 